\title{
Algerian Housing Policies
}

\author{
Riadh Djafri, Mariana Mohamed Osman, \\ Noor Suzilawati Rabe, Syafiee Shuid
}

Kulliyyah of Architecture and Environmental Design International Islamic University Malaysia

djafri.riadh@live.iium.edu.my, mariana@iium.edu.my, suzilawati@iium.edu.my, ssyafiee@iium.edu.my

\begin{abstract}
Despite being one of the richest countries in Africa, Algeria's affordable housing is still out of reach for low and even middle-income Algerians. Nowadays, Algeria is still suffering from housing shortage in terms of quality, affordability and number of units. The paper describes the Algerian Housing Policies using qualitative method of semi-structured interviews. The findings revealed that new mechanisms need to be injected and the housing agencies structure need to adopt an effective local, regional and national policies to promote the housing sector in terms of its quality and adequacy to the Algerian society which certainly will improve the overall Algerian quality of life.
\end{abstract}

Keywords: Housing policies; Housing quality; Algerian society; Quality of life

eISSN 2514-751X @ 2019. The Authors. Published for AMER ABRA CE-Bs by e-International Publishing House, Ltd., UK. This is an open-access article under the CC BY-NC-ND license (http://creativecommons.org/licenses/bync-nd/4.0/). Peer-review under responsibility of AMER (Association of Malaysian Environment-Behaviour Researchers), ABRA (Association of Behavioural Researchers on Asians) and cE-Bs (Centre for EnvironmentBehaviour Studies), Faculty of Architecture, Planning \& Surveying, Universiti Teknologi MARA, Malaysia. DOI: https://doi.org/10.21834/aje-bs.v4i13.349 


\subsection{Introduction}

Housing is considered the main responsibility of the government in many developing countries. In Africa, the pressure on urban infrastructure and housing provision is increasing in tandem with the rapid development and urbanisation of urban area. However, many countries in Africa, including Algeria is facing problem in the provision of quality, adequate and affordable housing and these have led to the rising of slums and squatter area in urban development with slum proportions of 11.8 per cent (El-hadj, Faye, \& Geh, 2018). Other issues such as housing deficit, urban sprawl in major cities and accelerating loss of agricultural lands are also issues faced by these African Countries. With the migration of rural people to urban areas looking for better quality of life, the demand for housing units has increased together with urban infrastructure, which usually led to overcrowding issues in big cities (Berrisford, S., DeGroot, D., Kihato, M., Marrengane, N., Mhlanga, Z., \& Van Den Brink, 2008). In Algeria context, increase number of housing units were developed and constructed in the last two decades under four national development plans adopted by the Algerian government. Nevertheless, the housing crisis is unable to be addressed. Furthermore, it is reported that 17 African countries are having a housing crisis with a shortage of more than 1 million units in each country. Thus, if the same trend continues, many urban problems will arise, and the situation will become worse with poor urban planning and inadequate housing supply throughout the African countries (El-hadj et al., 2018).

Currently, there are five types of housing programmes in Algeria plan for all levels of income (high-, middle- and low-income). The state considered that it is necessary to provide and facilitate the access to housing and solve the housing problems as this is the important element in providing the basic necessity and directly help to sustain a good quality of life among the people (Centre for affordable housing finance in Africa, 2017; MHUV, 2018).

The house-price-to-income ratio is an important factor to evaluate housing affordability. The ratio is calculated by dividing the house price by the median income of a country. In Algeria, the indicator of affordability is still out of reach where it touched 2.7 (El-hadj et al., 2018). Algeria, the biggest country in Africa, had an urbanisation rate of 2.76 per cent annually between 2010 and 2015, with an urban area constitute of more than $71 \%$ of the country (The World Bank Group, 2017). In addition, it was estimated to have a deficit of housing unit of at least 1.2 million units (El-hadj et al., 2018). According to the national office of statistics 2017, the Unemployment rate reached 11.2 in 2015 with a national minimum wage of 18000 DZD.

Earlier, the provision of housing in rural areas was by reconstruction thousands of units, which were demolished during the Algerian revolution war (1954-1962). Many housing projects were launched without preliminary studies and preparation. The majority of these housings were of poor quality in terms of the layout of housing and the used materials and bad located which were far from different infrastructure and facilities. Thus, it was vacant after finishing constructing (Hadjii, 1992). Furthermore, since 1999, Algeria has recovered political and institutional stability. The financial situation improved as a result of rising oil prices, and a new era for housing sector started. According to official figures, 810000 housing units were built during the period 1999-2004 (Ministère de l'Habitat et de 
I'Urbanisme, 2011). However, Bellal (2009) reported that for 20 years, the Algerian housing policy has achieved considerable progress. This can be shown in the period from 1991 to 2012. The housing sector is considered as great importance due to its social economic and politic influence. In fact, housing units are not only a shelter, but it ensures the stability and security of families. It also contributes to the satisfaction of the social and political climate. Over the last decades, the Algerian authorities have implemented huge programmes in order to upgrade the housing sector and offer a decent and suitable house for each Algerian family (Djiar, Gharbi, Messaoudene, \& Chareb, 2015).

Consequently, a huge number of housing units were constructed and delivered in the last two decades under the four development plans adopted by Algerian government between 2001 and 2019. In fact, Algerian housing policy strives to improve the living conditions and quality of life by offering adequate, decent and affordable housing for low and middle-income (Elketbi, 2017).

Earlier studies identified that the state was injecting a considerable budget into housing programs, but the problem still exists in terms of both housing supply, and housing quality and affordability (Benamrane, 1980; Ministry of Housing, 1986). Nowadays, it is clear that African countries including Algeria are making housing sector as the main agenda and trying to solve the issue before it becomes a housing crisis. Thus, there is a need to get the private sector involvement in the efforts of governments to address the housing issue (El-hadj et al., 2018).

Very few studies, however, have addressed the issues of housing policies in the context of Algeria. Thus, this study aims to clarify the current housing policies adopted by Algerian government and the encountered issues. Furthermore, the quality and adequacy of housing units to the Algerian quality of life will be discussed before proposing the solutions and recommendations in order to improve the overall housing quality.

\subsection{Overview of the Algerian Housing Policies}

The housing sector in Algeria is known to develop slowly by first providing basic shelter to families and later trying to offer decent, adequate and affordable accommodation for citizens of low and middle-income throughout Algeria. In the 1960s, the Algerian government stated that the housing units inherited from the French colonial administration were estimated to be around 1.7 million dwellings which were considered sufficient for the Algerian population at that time. Later, the housing sector was marginalised after independence in 1962, and the Ministry of Housing and Construction was formed only in 1977, i.e., 15 years after the independence. In addition, the plan of Constantine, which was an economic program designed by the French government in 1958 and which lasted for 26 months, aimed to construct two hundred thousand housing units in urban area and 110,000 housing units in rural area, allowing the provision to accommodate more than one million people. It was an attempt to improve the quality of life of Algerians living in selected urban and rural areas. However, the initiative did not achieve its objectives because it was used to terminate during the Algerian revolution (Djiar, 2014). 
Lalonde (2010) reported that the urban planning policies during the colonisation period were not adequate for address the physical, social and cultural characteristics of residents at that time, which has aggravated the problem in housing provision. However, the Algerian housing sector during that period was provided to ensure the influence of French culture and politics into the Algerian society during the colonisation period, and to integrate Algerian citizens into the culture of French society.

After the independence of the country, design of housing in Algeria is limited to the government specifications and influenced by the guidelines prepared and imposed by the concerned authorities. This has posed some design limitations and obstacle for Algerian architects and housing developer that want to offer a new design with better architecture and design style (Lalonde, 2010).

According to Mohamed (2015), the year of 1990 witnessed the rupture in the field of urbanism and the land use planning, which influenced the city and its environment. This was due to the lack of instructions based on the reality and the weakness of instruments at different levels; national, regional and local, which accelerate the tremendous development of urbanization, at the expense of agricultural land. On the other hand, new actors were involved in the production of the building frame in Algerian cities without complying with the rules of architecture and construction contained in the building permit. This has led to the creation of shanty towns.

Despite the strategies and efforts stated in the different development plans since independence, many problems are still ongoing in the housing sector such as the shortage of construction materials, inappropriate techniques of construction and the incompetence and lack of experience and knowledge of the local construction companies in the overall housing and construction industry. Hence, various authors conclude that the Algerian housing policy is considered fail to overcome the overall housing problem, despite the huge financial assistance allocated to the public and private housing programs (Abdelkarim, 2012; Behloul, 1991; Bellal, 2009; Djiar, 2014; Guendouz, Gasmi, \& Belhimer, 2017; Hadjri, 1992; Lalonde, 2010; Madani, 2012; Mouaziz-Bouchentouf, 2018; Saada, 1999).

In Algeria, the housing sector is an essential component of the public investment and several agencies are involved and working together to overcome the housing issues. This by facilitating the access to the house and ease the payment procedures in order to develop and improve this sector.

\subsection{Reviewing the agencies involved in housing sector in Algeria}

In Algeria, there are several agencies involved in construction and management of housing but with different objectives and scope/tasks. This including the Office of Promotion and Real Estate Management (OPGI); National Agency for Housing Improvement and Development (AADL); The National Housing Fund (CNL); and National Company for Real Estate Development (ENPI). The next section will briefly review the role of each agency within the housing sector.

\subsubsection{The Office of Promotion and Real Estate Management (OPGI):}

The office of promotion and management of real estate is a government agency with financial 
independence and subject to the rules of commercial law. The real estate promotion and management agency can carry out their activities at the national level. The development and real estate management offices located within the framework of social policy in the state and function to promote the public service in the field of housing, especially to the most disadvantaged social groups. In addition, its work lies in real estate promotion; upgrade the property; restoration of real estate properties, rehabilitation and maintenance (MHUV, 2018). 2.1.2 National Agency for Housing Improvement and Development (AADL):

The Algerian Agency for Housing Improvement and Development (AADL) created in 1991 by Decree No. 91-148 of 12 May 1991 in the form of a public institution of an industrial and commercial nature under the supervision of the Ministry of Housing. The AADL has a public service mission with legal functions, responsibility and financial autonomy. Its missions are as follows: the promotion and development of the land and real estate market; restoration of dangerous housing units; renovation and restoration of old urban fabrics; urban restoration; creation of new cities; development and popularization for their development, innovative construction methods through its action program (MHUV, 2018; Mouaziz-Bouchentouf, 2018).

\subsubsection{The National Housing Fund (CNL):}

The National Housing Fund (CNL) is a public institution of an industrial and commercial nature, created in 1991 and placed under the ministry of housing. The missions and attributions of CNL are to manage the state's contributions and subsidies for housing, particularly in terms of rents, the reduction of precarious housing, urban restructuring, rehabilitation and maintenance of the built environment and promoting social housing. In addition, the CNL also promote all forms of financing of housing such as Lease to own programme (AADL), promotional housing helped (LPA) and rural housing by mobilizing sources of funding for design offices and construction companies contracted and/or subsidises for house's beneficiary (Abdelkarim, 2012; Mouaziz-Bouchentouf, 2018).

\subsubsection{National Company for Real Estate Development (ENPI):}

The National Company for Real Estate Development (ENPI), a state-owned company involved in the commercial development of real estate, and in particular the acquisition of land, the construction of real estate, the sale and purchase of buildings and their rehabilitation, renovation or restructuring to ensure the financial viability of its subsidized housing program. In addition, the ENPI responsible for real estate management, advice and assistance in heritage management, and construction of the Promotional Public Housing (LPP) programme (Groupe de la banque mondiale, 2017).

From the foregoing discussion on the different agencies involved in the housing sector in Algeria focusing on the strategies and procedures and how they are practised, it can be concluded that the housing sector has different agencies with different tasks. This is to ensure the realisation and management of all types of housing offered in Algeria.

\subsection{Different National Development Plans from 2001 To 2019}

From 2001 to 2019, Algerian government adopted four national programs in order to upgrade 
the local economy and improve the housing sector in particular. Huge budgets were allocated to implement these plans and improve different sectors including housing. This part will focus on the different programs, policies and efforts adopted by the Algerian government to tackle the housing crisis as well as their impact on the Algerian society and the quality of life.

\subsection{The First National Development Plan (2001-2004)}

This plan was implemented as a program to support the economy with a budget of approximately 6.9 billion dollars, which is about 525 billion dinars. The program focused mainly on four sectors which are: (1) productive activities; (2) local development and welfare; (3) improvement of public services; and (4) human resource development (Centre for administrative innovation in the Euro.Mediterranean Region, n.d.). In addition, the improvement of the quality of life by developing productivity and suitability of the country, fixing new laws, policies and instructions with a view to upgrading the environment sector particularly was a priority in this program (The World Bank, 2002).

\subsection{The Second National Development Plan (2005-2009)}

The second plan was dedicated to supporting local growth between 2005 and 2009 with a budget of approximately 130 billion dollars (Messai, 2012). The housing sector was a priority in this plan by planning to construct one million housing units throughout the country. Furthermore, the objective was to boost the health, education, security and housing sectors and provide accommodation, schools, and to upgrade different public facilities and amenities, in order to improve the living conditions of the population (Guendouz et al., 2017).

The program to build one million housing units was completed by the end of 2009 , with $58 \%$ for urban housing and $42 \%$ for rural housing. With the number of housing units that have been delivered in this program, the gross housing occupancy rate registered a significant improvement from 5.79 per housing units in 1998 to 4.89 at the end of 2009 (Ministère de l'Habitat et de l'Urbanisme, 2011).

\subsection{The Third National Development Plan (2010-2014)}

The third plan was a completion of the second with a budget of 286 billion dollars, of which 50 billion dollars were allocated to the housing sector to construct two million housing units by the end of 2014 and upgrade the urban fabric. Only 1.2 million units were constructed in this four-year plan, so the remaining were deferred to the period 2015-2017. In addition, 40\% of the budget was allocated for hospitals, schools, colleges and different institutions. This program aimed to implement new housing policies to improve transparency and equity for getting housing and respecting the deadlines for completion and distributing housing units (Statement of the meeting of the Council of Ministers, 2014). The plan emphasised the continuation of rehabilitation of old buildings and upgrading degraded neighbourhoods, the use of new techniques and materials, the restructuring of national tools for improving the management of the housing sector (Ministère de l'Habitat et de l'Urbanisme, 2009). 


\subsection{The Fourth National Development Plan (2015-2019)}

The fourth plan between 2015 and 2019 has a budget of 280 billion dollars. It is a continuation of the previous schemes. According to Ministère de l'Habitat de l'Urbanisme et de la Ville (2015), the main objective of this program is to achieve an annual growth rate of $7 \%$ in order to improve the quality of life and living conditions of Algerian citizens. With regard to the housing sector, the effort of government will continue to implement the provision of housing in line with previous plans aimed at overcoming the housing crisis by the end of 2019 and finalising the slum eradication program at the end of 2015. Thus, 1.6 million units of all housing types are under construction throughout Algeria. This to confirm the commitment to implementing and improving housing quality, overcoming the shortage, and eliminating precarious housing. Statistics show that there has been an improvement in the occupancy rate of housing from 4.89 persons at the end of 2009 to 4.55 at the end of 2014. Furthermore, the figure is projected to reach 9.9 million housing units with more than 41 million of the population at the end of 2019 .

According to the national Algerian office of statistics, by 2030, the rate of occupation would be 4.14 persons per housing unit. In addition, the encouragement of private investment to take part in the construction and development of new cities and urban centres was included in this program (Services du Premier Ministre, 2017).

\subsection{Issues Encountered in Housing Sector in Algeria}

As stated earlier, even though the Algerian government is trying to address various housing issues through the implementation and provision of various housing programmes throughout Algeria, however, the country is still facing serious housing shortage and if this situation continues at the same pace, other problems such as poor quality of housing, squatter slums which influence the overall quality of life (El-hadj et al., 2018).

Housing policies in Algeria is mainly concentrated on the construction of a huge number of housing units for the purpose of low rental scheme and even full subsidised public housing units. In fact, the government is unable to respond to the current demand for housing ownership especially affordable housing market issue (El-hadj et al., 2018). It was reported that the demand for these programmes is far exceeded the supply, especially in the lowincome group housing segment. Many efforts have been done to overcome this issue, nevertheless, the problem is still ongoing (Centre for affordable housing finance in Africa, 2017).

According to the Centre for affordable housing finance in Africa (2017), several issues identified that lead to the housing crisis in Algeria, namely the bureaucratic and various administrative process within the approval of housing development, and also the mismanagement of funds of many housing projects that led to the decrease of housing completion unit from 165000 to less than 100000 units completed. In addition, several deficits have reported for the housing units under construction such as failure to respect the completion dates, unfulfilled commitments, and the absence of technical inspection which directly influence the quality of housing. Secondly, the limited land availability in some areas 
has largely contributed to restricting the growth of real estate market although the state is the primary owner of land in Algeria. The ownership of land by private developers are very limited and these have led to private housing sector to be very expensive and only cater to the highincome group. The low supply of land ownership among private developer has led to high housing prices which resulted in high rental market for private housing sector. Thirdly, the majority of households depend on public housing programmes and other strategies such as self-building on informally land and buying units in informal market to cater their need for housing. The massive price gaps between the private property market and affordable housing offered by the state have led to the creation of informal or illegal housing market in which, many units of housing are being built and sold but the ownership transfer cannot be done officially or not officially registered. Finally, the financial and funding for the government's programmes was problematic in 2017 , where the state banks promised to pay 11 billion dollars in 2013 to finance the housing programmes but only 1.38 billion dollars were paid between 2013 and 2015. This has led to the construction companies to stop construction of the approved social housing and other types of housing programmes.

\subsection{Methodology}

This study uses of the quantitative method through descriptive approach and interviews to examine the Algerian housing policies in urban area in terms of quality, affordability and number of units, and also to address the issue that hampers the improvement of this sector which influences directly the Algerian quality of life. As such, the sampling of the respondents will be considered purposive sampling. Neuman (1997) claimed that the appropriate sampling is purposive for developing a study in a deep way to truly understand the phenomena.

A face-to-face semi-structured interviews were conducted in this study, the advantage to use this type of interview is that the interviewer can control the process of getting information from the interviewee, in which the researcher does not strictly follow the formalised questions. This by asking more open ended questions and new sub-questions may arise during the discussion with the interviewee (Partington, 2001).

Accordingly, in order to achieve the desired results and meet the objective, this study attempts to answer the following four main questions: What are the current policies adopted by the Algerian government regarding the housing sector in urban area? And how do you evaluate the housing sector in Algeria in terms of quality and quantity? Do you think that the current housing quality is adequate to the quality of life of the Algerian society? What steps are you taking to improve the housing quality and reduce shortage issue?

The interviews were performed in Arabic and English. Interviews sessions ranged between 20 and 40 minutes. The recording interviews were transcribed verbatim, this process was used to make sense of the data (Creswell, 2008).

The choice of interviewees was based on selecting the different stockholders involved in the housing sector in Algeria through four selected interviews with experts in their field. They are attached to different organisations within both public and private sectors. The interviewees hold important positions and have vast experience and better understanding of 
overall housing policies and issues. Table 1 illustrates the details of the interviews involved in this study.

Table 1: List of interviewees for Qualitative Interviews

\begin{tabular}{|c|c|c|c|c|c|}
\hline $\begin{array}{c}\text { Participant ID/ } \\
\text { Date of interview }\end{array}$ & Organisation & Position & Age & $\begin{array}{l}\text { Working } \\
\text { experience }\end{array}$ & Responsibility \\
\hline $\begin{array}{l}\text { Participant \#1 } \\
\text { (16/09/2018) }\end{array}$ & $\begin{array}{c}\text { Owner of an } \\
\text { Architecture } \\
\text { office }\end{array}$ & $\begin{array}{c}\text { Expert } \\
\text { Architect in } \\
\text { housing }\end{array}$ & 58 & $\begin{array}{c}24 \text { Years } \\
\text { Architect } \\
\text { practitioner } \\
\text { specialises in } \\
\text { housing }\end{array}$ & $\begin{array}{c}\text { Housing } \\
\text { management and } \\
\text { design }\end{array}$ \\
\hline $\begin{array}{l}\text { Participant \#2 } \\
\text { (02/09/2018) }\end{array}$ & $\begin{array}{l}\text { Department of } \\
\text { housing in }\end{array}$ & $\begin{array}{c}\text { Director of } \\
\text { Housing }\end{array}$ & 51 & $\begin{array}{l}26 \text { Years in } \\
\text { housing } \\
\text { department }\end{array}$ & $\begin{array}{c}\text { Management and } \\
\text { supervision of } \\
\text { Housing } \\
\text { Department }\end{array}$ \\
\hline $\begin{array}{l}\text { Participant \#3 } \\
(27 / 08 / 2018)\end{array}$ & OPGI & $\begin{array}{l}\text { Head of } \\
\text { study and } \\
\text { realization } \\
\text { service }\end{array}$ & 58 & $\begin{array}{c}30 \text { Years in } \\
\text { OPGI }\end{array}$ & $\begin{array}{l}\text { Manage } \\
\text { architectural } \\
\text { contests of } \\
\text { housing }\end{array}$ \\
\hline $\begin{array}{l}\text { Participant \#4 } \\
\text { (27/08/2018) }\end{array}$ & OPGI & $\begin{array}{l}\text { Project } \\
\text { Manager }\end{array}$ & 45 & $\begin{array}{c}16 \text { Years in } \\
\text { OPGI }\end{array}$ & $\begin{array}{l}\text { Project monitoring } \\
\text { and control }\end{array}$ \\
\hline
\end{tabular}

The qualitative data were analysed using thematic analysis method. Thematic analysis is the procedure of classifying patterns or themes within qualitative data. Identifying the themes that are important and interesting in the data is the main objective of thematic analysis (Maguire \& Delahunt, 2017). As such, these themes are used to address the research questions and objectives to solve the issue which makes sense of it. Braun \& Clarke (2008) developed a six-phases of thematic analysis which is a crucial framework to follow when analysing this kind of data. These phases were followed when analysed the qualitative interview of the study which are; get familiarised with the data, generating initial codes, searching for themes, reviewing themes, defining and naming themes, producing the report.

\subsection{Result and Discussion}

Data of this study consists of a total of four interviews as shown in Table 1. The identities of the respondents were kept confidential by assigning pseudonyms of P1 for Participant 1, P2 for Participant 2, P3 for Participant 3, and P4 for Participant 4. The interpretation of the findings is organized along with the study's research questions and sub-questions, the themes that emerged through the participants' responses. The transcription produced three major themes namely; housing policies in terms of quality and quantity, housing adequacy and quality of life, improvement of housing quality.

\subsection{Housing policies in terms of quality and quantity:}

The current study revealed that all participants reported that the government has a lack in 
terms of potentiality despite the realisation of a considerable number of units. The respondents commented:

'The housing policies adopted by Algerian government currently is to construct a huge number of unit regardless the quality. Meanwhile, the government is trying to find new types and forms of housing with new options of payment to ease access to housing for everyone. This can be seen when the government injected a new type every time" (Participant \#1).

"Regarding the housing policies adopted in Algeria, there is a problem of potentiality despite constructing a huge number of housing units, but the demand is still far from the supply. So that the contractor and companies are limited in terms of construction materials to ensure the execution on time and with good quality" (Participant \#1).

"The quantity that has been constructed and delivered especially during the two last decades is huge. This can be confirmed by looking to the housing occupancy rate which reached 4.7 persons by unit. This is a good indicator in terms of the quantity aspect, but the demand is still a bit far from the supply... it is pretended to reach 4.5 after one year " (Participant \#2).

"To me, the quantity is enough, but the mismanagement of delivering these units has led to creating new issues....so many units are vacant due to the bureaucratic practices" (Participant \#4).

This finding is consistent with Centre for affordable housing finance in Africa (2017), which claimed that the demand exceeds the supply despite the effort made by the government. In addition, most of the respondents added that the units built so far is considered a huge compared to what has been done before two decades. While the quality is still out of the residents' expectation. The respondent commented as follows:

"For the quality, the administrator who charges the realisation and construction of housing units made it very limited, so architects are limited by these specifications and the result is shown in all types of housing throughout Algeria. The proof is obvious by the modification in terms of design and layout made by the residents once occupied the units" (Participant \#1).

"In terms of quality, there is a considerable improvement especially for social housing units because the housing agencies had the experience in this field, but it is not the case for the other types such as $A A D L$ and LPA. Nevertheless, an effort need to be done to ensure the quality expected by the residents" (Participant \#3).

In terms of quality, it is not acceptable in most cases, even though the injecting of new materials and techniques that seem to be not suitable... and the open spaces are not treated well which directly influence the quality" (Participant \#4).

From the above results, the finding of this explains what has been found by (El-hadj et al., 2018) regarding the shortage of number of units. The interviewee explained this shortage as mismanagement of delivery, especially for social housing type which is dedicated to the disadvantaged group. Nevertheless, majority of these units were delivered for those who don't deserve it. This is also in line with Centre for affordable housing finance in Africa (2017) which reported that the bureaucratic and various administrative process within the approval of housing development one of the main reasons of housing shortage.

However, in terms of housing quality, the respondent claimed that new techniques and materials were injected to improve the quality of housing, but the limitation of guidelines imposed by the authorities and lack of performed tools for the construction process makes the architects restricted to improve the design and the overall quality. This is supported by 
the finding of Benamrane (1980), Ministry of Housing (1986) and El-hadj et al., (2018) who argued that the quality of housing in Algeria is deteriorated despite inserting new techniques and materials.

\subsection{Housing adequacy and quality of life:}

In response to this question, most of the respondents believed that the housing delivered are not adequate to the Algerian society in most cases. The participants stated:

"The quality of life in Algeria still not clear and not well defined... The types of housing units offered in Algeria are not adequate to the Algerian society in most cases so the Algerian identity is threatened with extinction "(Participant \#1).

"For the adequacy of housing to the Algerian quality of life, it can be said that majority of occupants are not satisfied especially for the new housing introduced by the government such as AADL programme. This is due to the lack of experience and mismanagement which influenced the quality of housing units" (Participant \#3).

"The Algerian quality of life has been improving and changing with time, but the units still not adequate in terms of interior design, functionality and the surrounding environment" (Participant \#4).

This finding is consistent with those of (Abdelkarim, 2012; Behloul, 1991; Bellal, 2009; Djiar, 2014; Guendouz, Gasmi, \& Belhimer, 2017; Hadjri, 1992; Lalonde, 2010; Madani, 2012; Mouaziz-Bouchentouf, 2018; Saada, 1999) who argued that the main reasons behind the housing crisis are shortage of construction materials, inappropriate techniques of construction and the incompetence and lack of experience.

In contrary, Participant \#2 claimed that:

"The ministry of housing is offering several types of housing according to the climate and the living condition of each region, as Algeria is a vast country and the climate differs from region to another. This by offering the collective type, semi collective and even individual type in the south region (desert) to ensure the adequacy of every type to the specific living condition....so the ministry is trying to improve the guidelines and the specifications on a regular basis (Participant \#2).

It can be inferred from the above finding of P2 what has been stated in the literature review by the great effort made by the government to ensure everyone is having a suitable house. However, the variety is confirmed through the previous studies but the adequacy and the quality of these units to the Algerian society and its quality of life seem to be out of the expectation and needs to be improved.

\subsection{Improvement of housing quality:}

The respondents were well aware of the main issues and the solution that can contribute to the improvement, which is an important aspect to offer a good housing quality in order to meet the need of occupants and their expectations. The following quotes illustrate the point: "Overall, Algeria failed on its housing policies, despite constructing a huge number of housing units" (Participant \#1).

"The improvement can be done in terms of the control process during the construction and delivering the units. This by insuring it in a fair manner and by providing well-prepared specifications and guidelines defining the process, the whole process from the study to the delivering step" (Participant \#1).

"The improvement of housing sector in Algeria can be performed by focusing on architectural 
competitions which will ameliorate the quality. Furthermore, the use of new and suitable materials for construction and improving the surface of units. This will positively influence the quality of housing and ensure an adequate housing to the Algerian society" (Participant \#2).

"Improving the guidelines and specifications as well as the housing agencies structure. In other words, the structure of these agencies must be strict, accurate and well-defined to guarantee a good housing quality" (Participant \#3).

"The financing is a crucial factor to define and improve the housing sector in general, and the specification needs to be improved in terms of interior design, offer best conditions and choosing the finest companies" (Participant \#3).

"The financial factor followed by professional management is the most important aspect that determines both the quantity and quality" (Participant \#4).

\subsection{Conclusion}

After reviewing the four national development plans, the researcher identified the issues encountered in housing sector in Algeria and based on the interviews' findings, it can be concluded that Algeria still has a housing shortage to accommodate the demand of the population even though several programmes have been introduced to address this shortage. In addition, the housing quality and adequacy found to be out of reach of residents' expectations and their quality of life. It appears that the government is having problems in addressing these issues due to a combination of various factors such as a rapid growth Algeria ranked third in terms of urbanization in Africa- demographic growth, weakness of instruments, unstudied policies, poor governance and inadaptable guiding framework. Therefore, these recommendations are proposed; firstly, enabling the participation of the community as including all stakeholders in all phases of constructing housing is considered as a key success element. Secondly, there is a need for the provision of affordable, decent and adequate housing with a good quality, which meets the needs of Algerian society. This can be achieved by investigating and improving the factors influencing both the quality of housing as well as the quality of life by focusing on both architectural and urban scale. Thirdly, Algeria needs to improve the housing agencies structure and adopt an effective local, regional and national policies to promote the housing sector, which will certainly improve the living conditions and prevent the rise of slums, especially in urban areas. Finally, it is necessary to improve the building materials and techniques of construction by encouraging competition of effective and innovative architectural offices, institutions and companies as well as promoting the effectiveness in terms of financial management which will have a positive impact on quality, cost and construction time. The government need to plan and work together with the private housing developers by opening the doors to the foreign companies and collaborate within the country to come out with effective solutions and programmes in order to address the affordable housing provision. New inclusive, effective and innovative policy and programmes need to be planned with government agencies, public institutions and ministries together with other stakeholders in ensuring the provision of housing for all can be achieved. 


\section{References}

Abdelkarim, H. (2012). Evolution des politiques de I' habitat en algerie le L. S.P comme solution a la crise chronique du logement cas d' etude la ville de chelghoum laid. Université Ferhat Abbas Sétif, Algérie.

Behloul, M. (1991). Post occupancy evaluation of five story walk up dwellings : the case of four mass housing estates in Algiers. (University of Sheffield).

Bellal, T. (2009). Housing supply in Alegria: Affordability matters rather than availability. Theoretical and Empirical Researches in Urban Management, 4(3), 97-114.

Benamrane, D. (1980). Crise de l'habitat perspective de développement socialiste en Algérie (SNED). Algiers.

Berrisford, S., DeGroot, D., Kihato, M., Marrengane, N., Mhlanga, Z., \& Van Den Brink, R. (2008). In Search of Land and Housing in the New South Africa: The Case of Ethembalethu (World Bank Publications., Ed.). https://doi.org/10.1596/978-0-8213-7373-6

Braun, V., \& Clarke, V. (2008). Using thematic analysis in psychology. Qualitative Research in Psychology, 3(2), 77-101. https://doi.org/doi.org/10.1191/1478088706qp063oa

Centre for administrative innovation in the Euro.Mediterranean Region. (n.d.). Algeria Administrative Reform , Innovation and Maintenance. Retrieved from http://www.caimed.org

Centre for affordable housing finance in Africa. (2017). Housing Finance in Africa : A review of some of Africa's housing finance markets (8th ed.). Retrieved from

https://housingfinanceafrica.org/app/uploads/CAHF_smallpdf.pdf?x77297

Djiar, K. A. (2014). Politiques de l'habitat en Algerie. cinquante ans apres (Al-Djazair). Alger.

Djiar, K. A., Gharbi, M., Messaoudene, M., \& Chareb, O. (2015). Urban Renewal , Social Housing , Relocation , and Violence in Algiers. International Journal of Architectural and Environmental Engineering, 9(4).

El-hadj, M. B., Faye, I., \& Geh, Z. F. (2018). Housing Market Dynamics in Africa (2018th ed.). https://doi.org/10.1057/978-1-137-59792-2

Elketbi, M. (2017). The completion of public rental housing in Algeria. Building and Construction Legislation Magazine "165-147, مجلة تثربعات التعدير والبناء,"

Groupe de la banque mondiale. (2017). Rapport de suivi de la situation économique "Concevoir un programme efficace et durable pour le financement du logement social afin de promouvoir la prospérité partagée."

Guendouz, T., Gasmi, S., \& Belhimer, I. (2017). The Five-Year Development Plans in Algeria 2001-2014. Unemployment and Inflation. Human and Social Studies "215-189, مجلة دراسات انسانية واجتماعية,

Hadjri, K. (1992). Current Algerian housing policies affecting the methods for housing provision. Habitat International, 16(3), 71-78. https://doi.org/10.1016/0197-3975(92)90064-6

Lalonde, M. (2010). La crise du logement en Algérie : des politiques d'urbanisme mésadaptées. Université de Montréal.

Madani, S. Z. (2012). Le logement en algérie : programmes, enjeux et tensions. Confluences Méditerranée, 2(81), 133-152. https://doi.org/10.3917/come.081.0133 
Maguire, M., \& Delahunt, B. (2017). Doing a Thematic Analysis : A Practical , Step-by-Step Guide for Learning and Teaching Scholars . Journal of Teaching and Learning in Higher Eductaion, 3.

Messai, M. (2012). The policy of economic recovery in Algeria and its impact on growth. Journal of the Researcher, 10, 147-160.

MHUV. (2018). Ministère de l'Habitat, de l'Urbanisme et de la Ville. Retrieved August 25, 2018, from http://www.mhuv.gov.dz/Pages/Article.aspx?a=79

Ministère de l'Habitat de l'Urbanisme et de la Ville. (2015). Politiuqe gouvernementale dans le domaine de l'habitat, de l'hurbanisme et de la ville. Retrieved from http://www.premier-ministre.gov.dz/fr

Ministère de l'Habitat et de l'Urbanisme. (2009). Gagner la bataille de la qualité. Un millionde nouveaux logements. Revue de l'Habitat, 4.

Ministère de l'Habitat et de l'Urbanisme. (2011). Agir pour les réduction du risque sismique. Revue de l'Habitat, 6.

Ministry of Housing. (1986). "Situation et Perspectives." Algiers.

Mohamed, G. (2015). Instruments of Urban Planning in Algerian City: Reality and Challenges. Journal of Civil Engineering and Architecture, 9(7), 807-812. https://doi.org/10.17265/1934-7359/2015.07.007

Mouaziz-Bouchentouf, N. (2018). Histoire et politique de l'habitat en Algérie. Cours. Retrieved from https://www.univ-usto.dz/images/coursenligne/HPH.pdf

Neuman, W. L. (1997). Social research methods-Qualitative and quantitative approaches ((3rd ed.)). Boston, MA: Allyn \& Bacon.

Partington, G. (2001). Qualitative Research Interviews: Identifying Problems in Technique. Issues in Educational Research, 11(2), 32-44.

Saada, M. N. (1999). Housing Policy in Algeria. Issues and Perspectives. 1-14.

Services du Premier Ministre. (2017). Plan d'action du gouvernement pour la mise en œuvre du programme du president de la republique. Retrieved from http://www.premier-ministre.gov.dz/ressources/front/files/pdf/plans-dactions/plan-d-action-du-gouvernement-2017-fr.pdf

The World Bank. (2002). Algeria National Environmental Action Plan for Sustainable Development. Retrieved from http://hdl.handle.net/10986/15364

The World Bank Group. (2017). World development Indicators 2017. https://doi.org/10.1596/978-1-4648-0683-4 